Article

\title{
Regional Pelagic Rotifer Biodiversity in a Tropical Karst Lake District
}

\author{
Rocío Fernández ${ }^{\circledR}$, Javier Alcocer $*$ (i) and Luis A. Oseguera \\ Grupo de Investigación en Limnología Tropical, FES Iztacala, Universidad Nacional Autónoma de México, Av. \\ de los Barrios 1, Los Reyes Iztacala, Tlalnepantla, Estado de México, C.P. 54090, Mexico; \\ biol.fernandez@gmail.com (R.F.); loseguera@unam.mx (L.A.O.) \\ * Correspondence: jalcocer@unam.mx
}

Received: 19 August 2020; Accepted: 26 November 2020; Published: 28 November 2020

\begin{abstract}
The species richness, composition, abundance, and biomass of pelagic rotifers were determined in 17 karst lakes of the "Lagunas de Montebello" National Park, Chiapas, Mexico. The species richness of the region (21 species) and single lakes (1-12 species) was smaller than that of other Mexican, tropical, and temperate lakes. It is worth noting the high dissimilarity in species composition-about half (52\%) of the species were observed in only 1-3 lakes. A total of eight rotifer families, all from the Monogononta subclass, were recorded. Keratella americana was the species with the highest occurrence (13 lakes), followed by Ptygura sp. (8 lakes). The abundance (0 to 536 ind L $\left.\mathrm{L}^{-1}\right)$ and biomass ( 0 to $\left.21 \mu \mathrm{g} \mathrm{L}^{-1}\right)$ of rotifers were low. The highest values of species richness, abundance, and biomass were found in eutrophic lakes, and the lowest in oligotrophic lakes. The low values of rotifer biodiversity, abundance, and biomass in the Montebello lakes are probably the product of the interaction of different factors-such as environmental homogeneity (all water bodies are karst lakes), the low availability of "good-quality" food, and predation by cyclopoid copepods in the eutrophic lakes, and the low availability of food, and competitive interference by calanoid copepods and cladocerans in the oligotrophic lakes.
\end{abstract}

Keywords: species richness; abundance; biomass; trophic status; zooplankton; Montebello; Chiapas; Mexico

\section{Introduction}

Species diversity of terrestrial ecosystems increases in the tropics, which results in high biodiversity in tropical rainforests [1]. Mexico is one of the 12 top megadiverse countries holding $70 \%$ of the vertebrate (amphibians, reptiles, birds, and mammals) and vascular plant diversity worldwide [2]; however, the studies of aquatic invertebrates in Mexican freshwaters is scant, and to date [3], it is undetermined whether these inland aquatic ecosystems display the same tendency of high biodiversity that terrestrial communities show $[4,5]$.

Approximately 300 species of rotifers have been recorded in the epicontinental waters of Mexico [6]. Most inventories have been conducted in one or a few aquatic bodies (e.g., References [7,8]), with species richness ranging from 2 to 125 species per aquatic system [9-11] and densities ranging from 1 to more than 1000 ind $\mathrm{L}^{-1}$ (e.g., Reference [12]). Although regional rotifer studies in Mexico are rare, Walsh et al. [13] and Rios-Arana et al. [14] found 57 and 64 rotifer species in 47 and seven water bodies, respectively (e.g., saline ponds, desert springs, playa lakes), disseminated in the arid, northern territories of Mexico, while Arroyo-Castro et al. [15] reported 36 species from 17 karstic water bodies of the Cozumel Island. The three studies found that the water bodies within the same geographic region (i.e., lake district) share few rotifer species in common [13-15]. 
It is well known that both biotic (e.g., predation, competition [16,17]) and abiotic (e.g., rainfall, dissolved oxygen, temperature, turbidity [18-21]) factors influence the biodiversity of aquatic organisms. In temperate aquatic systems, biodiversity has been positively related to primary productivity [22,23] and the morphometry of lakes [24]. In recent decades, numerous aquatic ecosystems have been anthropogenically impacted, especially by agro-industrial practices [25], which have caused changes in the biodiversity of aquatic ecosystems [26] by extinguishing sensitive species or reducing beta diversity or functional diversity through habitat homogenization [27-29].

Located in the state of Chiapas, southern Mexico, the "Lagunas de Montebello" was designated National Park (1959), UNESCO-MAB Biosphere Reserve, Important Bird Area, and Wetland of International Importance Ramsar Site 1325 (2003). The "Lagunas de Montebello" National Park (PNLM) takes its name from the lake district, and consists of more than 60 karst lakes, which vary widely in size and depth [28]. Besides recognized as one of the most beautiful and pristine natural landscapes in the country, the basin has been included in the Water Reserve Program of CONAGUA/WWF as a National Water Reserve for the future (50 years). Despite the name of this National Park and Ramsar site (i.e., Lagunas de Montebello), the limnology of the lakes is essentially unknown [30].

As most Mexican epicontinental aquatic ecosystems, these lakes have not escaped anthropogenic impacts. Starting in 2003, changes in the coloration and transparency of the waters began to be reported in some of the lakes in the northwestern zone of the PNLM, evidencing a local eutrophication process [30,31].

The PNLM lakes constitute a natural laboratory in which to explore and recognize patterns of regional aquatic biodiversity-pelagic rotifers in this case-through a comparison between the numerous natural aquatic bodies that comprise the lake district. Furthermore, the eutrophication of some of these lakes makes it possible to recognize the effects of eutrophication on aquatic biodiversity by comparing the species richness and composition of planktonic rotifers in both pristine (oligotrophic) and impacted (eutrophic) systems.

Therefore, the aim of the present work was to study the biodiversity of pelagic rotifers in a set of PNLM lakes with different morphometric characteristics and trophic statuses. Likewise, we sought to reveal the biodiversity patterns of rotifers, as well as which of the evaluated characteristics (i.e., surface area, maximum and average depth, chlorophyll a concentration, total abundance of copepods, total abundance of cladocerans), have greater relevance in explaining the composition, species richness, abundance, and biomass of the different assemblages of pelagic rotifers of the PNLM lakes.

\section{Study Site}

The PNLM is in the southwestern portion of the state of Chiapas, bordering Guatemala. Its extreme coordinates are $16^{\circ} 04^{\prime} 40^{\prime \prime}-16^{\circ} 10^{\prime} 2^{\prime \prime} \mathrm{N}$ and $91^{\circ} 37^{\prime} 40^{\prime \prime}-91^{\circ} 47^{\prime} 40^{\prime \prime} \mathrm{W}$ (Figure 1); it extends over an area of $64.2 \mathrm{~km}^{2}$ in the municipalities of La Independencia and La Trinitaria [32]. The climate of the area is temperate, wet, with long summers, the mean annual temperature of $17.3^{\circ} \mathrm{C}$, and precipitation of $1800 \mathrm{~mm}$, and a warm-rainy season lasting from May to December [33].

The area is covered by Lower Cretaceous limestone and is associated with the formation of a karst lake complex composed of dolines, uvalas, and poljes [34] distributed along an elevation gradient of 1200-1800 $\mathrm{m}$ a.s.l. [30]. The basin is endorheic and is part of hydrological region number 30, Grijalva-Usumacinta, fed superficially by the Grande de Comitán River; however, due to its karst nature, the main water supply is underground [32].

A total of 17 lakes were chosen (Figure 1) following an NW-SE orientation along the fracture zone [34], which best represent the morphometric and trophic status (according to chlorophyll "a" concentration, Vera-Franco et al. [35]) diversity present in the area (Table 1). Geomorphologically the water bodies could be classified [36] in a) plateau lakes (at the NW, surface water fed, eutrophic) and b) mountain lakes (at the SE, groundwater fed, oligotrophic). Water depth and surface area-among other 
variables-determine the lake's thermal type. By incorporating both morphometric characteristics, the lakes turned out to be warm polymictic when shallow, while warm monomictic when deep.

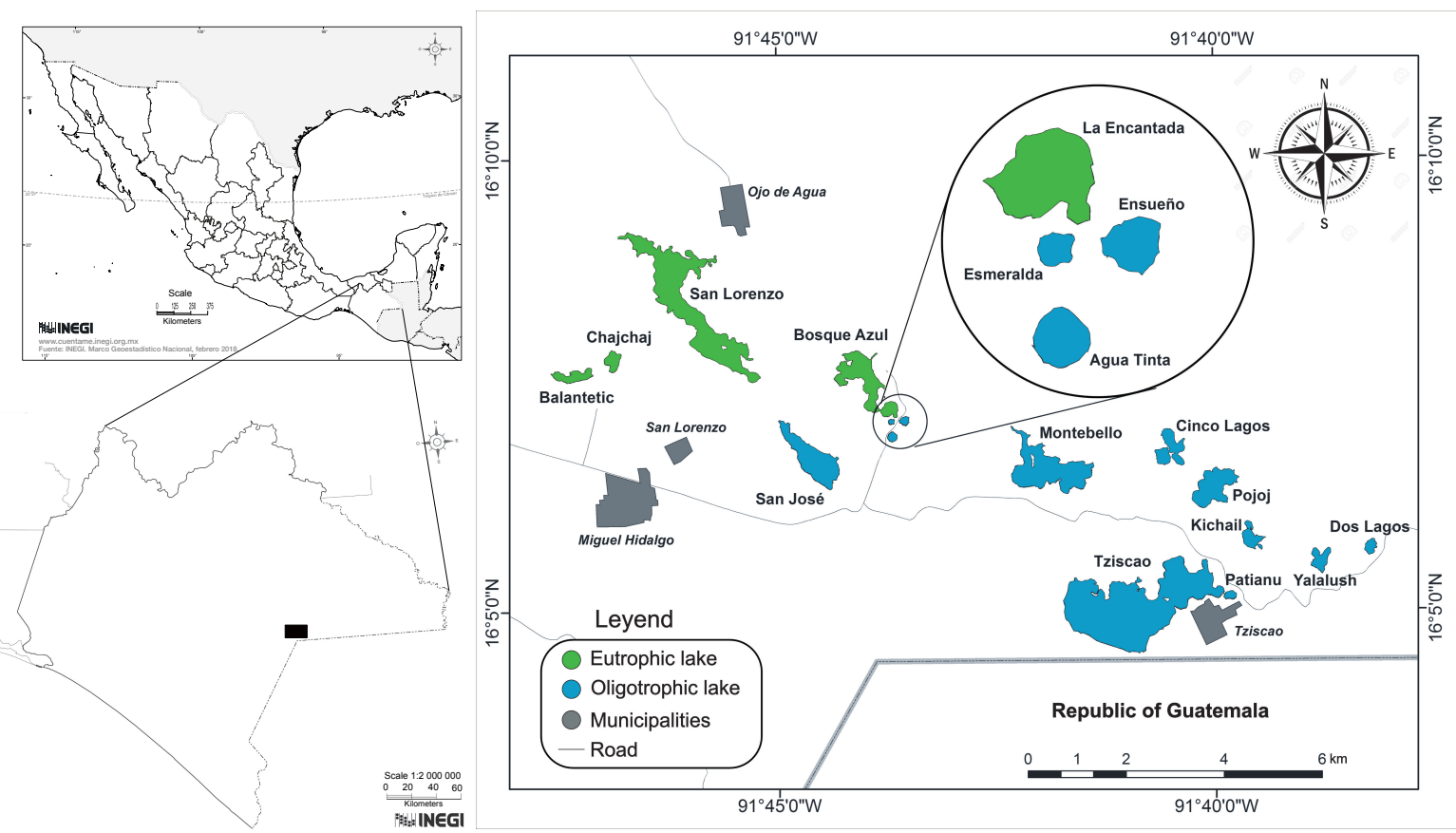

Figure 1. Location of the studied lakes of the "Lagunas de Montebello" National Park, Chiapas, Mexico.

Table 1. Morphometry $\left(\mathrm{A}=\right.$ surface area, $\mathrm{D}_{\mathrm{MAX}}=$ maximum depth, and $\mathrm{D}_{\mathrm{MEAN}}=$ mean depth), thermal type, and trophic status of the studied lakes of the "Lagunas de Montebello" National Park (PNLM), Chiapas, Mexico. Surface, depth, and thermal type are according to Alcocer et al. [28,33], while trophic status, according to Vera-Franco et al. [35]. (Abr. = lakes' names abbreviation).

\begin{tabular}{ccccccc}
\hline Lake & Abr. & $\begin{array}{c}\text { A } \\
(\mathbf{h a})\end{array}$ & $\begin{array}{c}\text { DMAX }_{\mathbf{( m )}} \\
\text { Balantetic }\end{array}$ & $\begin{array}{c}\text { D MEAN } \\
\mathbf{( m )}\end{array}$ & $\begin{array}{c}\text { DMEAN } \\
(\mathbf{m})\end{array}$ & $\begin{array}{c}\text { Trophic } \\
\text { Status }\end{array}$ \\
\hline Chajchaj & CH & 9.2 & 12 & 5.3 & Warm polymictic & Eutrophic \\
\hline San Lorenzo & SL & 181.3 & 67 & 11.8 & Warm monomictic & Eutrophic \\
\hline Bosque Azul & BA & 52.5 & 58 & 7.1 & Warm monomictic & Eutrophic \\
\hline La Encantada & EC & 8.2 & 89 & 27.5 & Warm monomictic & Eutrophic \\
\hline Esmeralda & ES & 1.1 & 7 & 3.6 & Warm polymictic & Oligotrophic \\
\hline Ensueño & EN & 2.7 & 35 & 21.6 & Warm monomictic & Oligotrophic \\
\hline Agua Tinta & AT & 3.0 & 24 & 14.7 & Warm monomictic & Oligotrophic \\
\hline San José & SJ & 60.6 & 30 & 10.3 & Warm monomictic & Oligotrophic \\
\hline Montebello & MB & 96.2 & 45 & 12.3 & Warm monomictic & Oligotrophic \\
\hline Cinco Lagos & CL & 23.7 & 162 & 42.5 & Warm monomictic & Oligotrophic \\
\hline Pojoj & PO & 43.7 & 198 & 35.2 & Warm monomictic & Oligotrophic \\
\hline Kichail & KI & 12.5 & 22 & 9.5 & Warm monomictic & Oligotrophic \\
\hline Tziscao & TZ & 306.6 & 86 & 28.9 & Warm monomictic & Oligotrophic \\
\hline Patianú & PA & 3.4 & 26 & 10.8 & Warm monomictic & Oligotrophic \\
\hline Yalalush & YA & 11.5 & 23 & 9.9 & Warm polymictic & Oligotrophic \\
\hline Dos Lagos & DL & 5.2 & 42 & 25.2 & Warm monomictic & Oligotrophic \\
\hline
\end{tabular}




\section{Methods}

Two sampling campaigns were carried out in 2015, corresponding to the two hydrologically contrasting seasons in which the largest differences were expected to occur. The first sampling campaign was in the cold and dry season (C, February), which represents the circulation season of the lakes, and the second campaign took place during the warm and rainy season (W, October), when the lakes are anticipated to be well stratified.

All lakes were sampled in the same way, following the same procedures, and all samples were analyzed equally. The water samples were obtained with a 5-L Uwitec water-sampling bottle in the pelagic zone corresponding to the central and deepest areas of the lakes. A 30-L water-column integrated sample was taken from each lake. The complete 30-L water sample was filtered in situ through a $54 \mu \mathrm{m}$ mesh size net, and all the retained organisms were concentrated in vials of $50 \mathrm{~mL}$ and fixed with $4 \%$ formaldehyde for further analysis. We analyzed (identified and counted) all individual concentrated in the 50-mL vials of each one of the 17 lakes for a total of 34 samples (17 from the cold and dry season, and 17 from the warm and rainy season). We counted the entire $50 \mathrm{~mL}$ samples; no sub-sampling (i.e., aliquot) method was used.

We first quantified the total zooplankton abundance using a Sedgwick Rafter chamber under an optical microscope. Rotifers were further separated from the rest of the zooplankton and identified using specialized taxonomic keys [6,37]. All rotifer names were confirmed with the World Rotifer Catalog (Jersabek and Leitner [38]) and the List of Available names (LAN) part Rotifera; International Commission of Zoological Nomenclature: http://iczn.org/lan/rotifer. The total zooplankton biomass was evaluated, according to Bonecker et al. [39]. The rotifer biomass was measured as biovolume calculated based on the geometric formulas proposed by Ruttner-Kolisko [40]. The wet weight was estimated from the biovolume of each individual [41]. The dry weight corresponds to $10 \%$ of the wet weight [42].

\section{Data Analysis}

A species accumulation curve was calculated, according to Ugland et al. [43] to estimate the number of species in the region (i.e., lake district) and indicate the adequacy of the rotifer survey in representing their biodiversity of Montebello lakes. We calculated alpha (species richness per lake) diversity. To identify the dissimilarity between the lakes, we used the Bray Curtis index. To compare the abundance and biomass of the rotifer communities of the lakes between both seasons (cold/dry and warm/rainy), a paired samples Student's $t$-test was used, and the data was $\ln$-transformed $[\ln (x+1)]$ to reduce skew distributions. To compare the rotifer communities (abundance and biomass) between eutrophic and oligotrophic lakes and between shallow and deep lakes, Student's $t$-tests for independent samples were used, since the " $n$ " of the lake groups are different and are not paired (eutrophic = 5; oligotrophic $=12$; shallow $=4$; deep $=13$ ). We first verified that normality (Kolmogorov-Smirnov test) and homogeneity (Levene test) of variance assumptions were met for all Student's $t$-test.

To describe the faunistic dissimilarity between lakes, the lakes were classified considering abundance values of the rotifer species $[\ln (x+1)]$ with a cluster analysis (UPGMA) based on the Bray Curtis dissimilarity index. A similarity percentage analysis (SIMPER) was performed on the rotifer species abundance data to identify the species most responsible for the formation of lake groups.

To explore the variables that better explained the lakes' similarity regarding rotifer species abundance, a canonical correspondence analysis (CCA) was carried out, including maximum and average depth, trophic status (as chlorophyll a concentration), surface area, total abundance of copepods, and total abundance of cladocerans as independent variables; while the rotifer species abundance was used as the dependent variable. Another equivalent CCA was carried out but now considering biomass of copepods, cladocerans, and rotifers instead of abundance. The statistical significance of the CCA analysis was tested using a Monte Carlo permutation test, and the variance inflation factors (VIF) of the variables were calculated to determine the possible linear dependencies. Student's $t$-tests and 
cluster were performed using IBM SPSS Statistics V25.0 and Bray Curtis index, SIMPER, and CCA with R Core Team [44].

\section{Results}

\subsection{Species Richness and Composition}

A total of 21 rotifer species belonging to the Monogononta subclass, represented by eight families, were identified in the pelagic zone of the lakes (Table 2). The regional species accumulation curve (Supplemental Materials Figure S1) suggests that this value is close to the actual species richness present in the PNLM. The species richness was 19 species ( $\approx 91 \%$ of total identified rotifers) for the cold/dry season and 16 species $(\approx 76 \%$ of total identified rotifers) for the warm/rainy season. The species richness per lake ranged from $1(5 \%)$ to $12(57 \%)$ species, with an average \pm standard deviation of $5.2 \pm 3.2$. A total of six lakes (Balantetic, Chajchaj, San Lorenzo, Bosque Azul, La Encantada, and Kichail) showed the highest species richness, with 7 to 12 species. The other 11 lakes had species richness values lower than 7 .

Out of the 21 species, 14 species (67\%) were found in both seasons; while five species (24\%) were found only in the cold/dry season and two species (10\%) were found only in the warm/rainy season. The species found only in the warm/rainy season were Lecane papuana and Macrochaetus sp., while those found only in the cold/dry season were Testudinella patina, Brachionus bidentatus, B. rubens, Platyias quadricornis, and Synchaeta oblonga.

A total of $18(86 \%)$ species were found in the eutrophic lakes, while $15(71 \%)$ were found in the oligotrophic lakes; six species (29\%, Filinia terminalis, Asplanchna girodi, Brachionus bidentatus, Plationus patulus, Platyias quadricornis, and Polyarthra vulgaris) were restricted to the eutrophic lakes, while three species ( $\approx 14 \%$, Ptygura sp., Synchaeta oblonga, and Macrochaetus sp.) were restricted to the oligotrophic lakes (Table 2). Most of the species, 12 (57\%), were found in both eutrophic and oligotrophic lakes.

Regarding the species richness, no significant differences were found between the seasons (Student's $t$-tests, $n=34, t=2.087, p=0.053$ ) and morphometry (Student's $t$-tests, $n=17, t=0.393$, $p=0.700$ ); while a significant difference was found (Student's $t$-tests, $n=34, t=6.714, p=0.000$ ) for trophic status with higher species richness in the eutrophic lakes with $10 \pm 2$ species compared to the oligotrophic lakes with only $4 \pm 2$ species.

Independent of the lake category, we found a high dissimilarity in species composition between lakes. Keratella americana was the species that occurred in most of the studied lakes (13 lakes, $\approx 77 \%$ of all investigated lakes), followed by Ptygura sp. (8 lakes, $\approx 47 \%$ ) and Filinia longiseta (7 lakes, $\approx 41 \%$ ). On the contrary, in total, around half (52\%) of the species were observed in only 1-3 lakes. 
Table 2. Taxonomic list of the planktonic rotifer assemblages of the lakes of the PNLM, Chiapas, Mexico, in both seasons $(\mathrm{C}=\mathrm{cold} / \mathrm{dry} ; \mathrm{W}=\mathrm{warm} / \mathrm{rain} y, \mathrm{~S}=$ species richness, Nr. = number of lakes where each species was recorded). (Abbreviations of lakes' names as in Table 1.).

\begin{tabular}{|c|c|c|c|c|c|c|c|c|c|c|c|c|c|c|c|c|c|c|}
\hline \multirow{2}{*}{ Phylum Rotifera Cuvier 1798} & \multicolumn{5}{|c|}{ Eutrophic } & \multicolumn{12}{|c|}{ Oligotrophic } & \multirow{2}{*}{ Nr. } \\
\hline & BL & $\mathrm{CH}$ & SL & BA & EC & ES & EN & AT & SJ & MB & CL & PO & KI & TZ & PA & YA & DL & \\
\hline \multicolumn{19}{|l|}{ Subclass Monogononta Plate, 1889} \\
\hline \multicolumn{19}{|l|}{ Order Flosculariaceae Harring, 1913} \\
\hline \multicolumn{19}{|l|}{ Family Hexarthridae Bartos, 1959} \\
\hline 1. Hexarthra intermedia (Wisniewski, 1929) & & & $\mathrm{C} / \mathrm{W}$ & $\mathrm{C} / \mathrm{W}$ & W & & $\mathrm{C}$ & & & & & & $\mathrm{C}$ & $\mathrm{C}$ & & & & 6 \\
\hline \multicolumn{19}{|l|}{ Family Testudinellidae Harring, 1913} \\
\hline 2. Testudinella patina (Hermann, 1783) & $\mathrm{C}$ & $\mathrm{C}$ & & & & & & & & & & & $\mathrm{C}$ & & & & & 3 \\
\hline 3. Ptygura sp. & & & & & & & $\mathrm{C} / \mathrm{W}$ & $\mathrm{C} / \mathrm{W}$ & & $\mathrm{C}$ & $\mathrm{C}$ & $\mathrm{C}$ & $\mathrm{C}$ & $\mathrm{C}$ & $\mathrm{C}$ & & & 8 \\
\hline \multicolumn{19}{|l|}{ Family Trochosphaeridae Harring, 1913} \\
\hline 4. Filinia longiseta (Ehrenberg, 1834) & $\mathrm{C} / \mathrm{W}$ & $\mathrm{C} / \mathrm{W}$ & $\mathrm{C} / \mathrm{W}$ & $\mathrm{C}$ & $\mathrm{C} / \mathrm{W}$ & & & & $\mathrm{W}$ & & & & & & $\mathrm{C}$ & & & 7 \\
\hline 5. F. terminalis (Plate, 1886) & & $\mathrm{W}$ & $\mathrm{C} / \mathrm{W}$ & $\mathrm{C}$ & & & & & & & & & & & & & & 3 \\
\hline \multicolumn{19}{|l|}{ Order Ploima (Hudson and Gosse, 1886) } \\
\hline \multicolumn{19}{|l|}{ Family Asplanchnidae Eckstein, 1883} \\
\hline 6. Asplanchna girodi de Guerne, 1888 & $\mathrm{~W}$ & $\mathrm{~W}$ & & & $\mathrm{C}$ & & & & & & & & & & & & & 3 \\
\hline \multicolumn{19}{|l|}{ Family Brachionidae Ehrenberg, 1838} \\
\hline 7. Brachionus angularis Gosse, 1851 & $\mathrm{C} / \mathrm{W}$ & $\mathrm{C} / \mathrm{W}$ & & & $\mathrm{C}$ & & $\mathrm{C}$ & & & & & & & $\mathrm{C}$ & & W & & 6 \\
\hline 8. B. bidentatus Anderson, 1889 & $\mathrm{C}$ & & & & & & & & & & & & & & & & & 1 \\
\hline 9. B. calyciflorus species complex Pallas, 1766 & $\mathrm{C} / \mathrm{W}$ & $\mathrm{C} / \mathrm{W}$ & & $\mathrm{W}$ & & & & & & & & & & & $\mathrm{C}$ & $\mathrm{W}$ & $\mathrm{W}$ & 6 \\
\hline 10. B. havanaensis Rousselet, 1911 & & $\mathrm{C} / \mathrm{W}$ & $\mathrm{C} / \mathrm{W}$ & $\mathrm{C}$ & $\mathrm{C}$ & & & & & & $\mathrm{C}$ & & & & $\mathrm{C}$ & & & 6 \\
\hline 11. B. rubens Ehrenberg, 1838 & & & & $\mathrm{C}$ & & & & $\mathrm{C}$ & & & & & & & & & & 2 \\
\hline 12. Keratella americana Carlin 1943 & & $\mathrm{C} / \mathrm{W}$ & $\mathrm{C} / \mathrm{W}$ & $\mathrm{C} / \mathrm{W}$ & $\mathrm{C} / \mathrm{W}$ & & $\mathrm{C} / \mathrm{W}$ & & $\mathrm{C} / \mathrm{W}$ & $\mathrm{C}$ & $\mathrm{C} / \mathrm{W}$ & $\mathrm{C} / \mathrm{W}$ & $\mathrm{C} / \mathrm{W}$ & $\mathrm{C} / \mathrm{W}$ & $\mathrm{C}$ & & $\mathrm{C} / \mathrm{W}$ & 13 \\
\hline 13. K. cochlearis (Gosse, 1851) & & $\mathrm{C} / \mathrm{W}$ & $\mathrm{C} / \mathrm{W}$ & & $\mathrm{C} / \mathrm{W}$ & & & & & & & & $\mathrm{C}$ & & & & & 4 \\
\hline 14. K. tropica (Apstein, 1907) & & $\mathrm{C} / \mathrm{W}$ & $\mathrm{C} / \mathrm{W}$ & $\mathrm{C} / \mathrm{W}$ & & & & & & & & & $\mathrm{C}$ & & & & $\mathrm{C} / \mathrm{W}$ & 5 \\
\hline 15. Plationus patulus (Müller, 1786) & $\mathrm{C} / \mathrm{W}$ & $\mathrm{W}$ & $\mathrm{W}$ & & & & & & & & & & & & & & & 3 \\
\hline
\end{tabular}


Table 2. Cont

\begin{tabular}{|c|c|c|c|c|c|c|c|c|c|c|c|c|c|c|c|c|c|c|}
\hline \multirow{2}{*}{ Phylum Rotifera Cuvier 1798} & \multicolumn{5}{|c|}{ Eutrophic } & \multicolumn{12}{|c|}{ Oligotrophic } & \multirow{2}{*}{$\mathrm{Nr}$} \\
\hline & BL & $\mathrm{CH}$ & SL & BA & EC & ES & EN & AT & SJ & MB & CL & PO & KI & $\mathrm{TZ}$ & PA & YA & DL & \\
\hline 16. Platyias quadricornis (Ehrenberg, 1832) & & & & $\mathrm{C}$ & & & & & & & & & & & & & & 1 \\
\hline \multicolumn{19}{|l|}{ Family Lecanidae Remane, 1933} \\
\hline 17. Lecane bulla (Gosse, 1851) & W & & $\mathrm{C} / \mathrm{W}$ & & $\mathrm{C}$ & & & & & & & & $\mathrm{W}$ & $\mathrm{C}$ & & & $\mathrm{C}$ & 6 \\
\hline 18. L. papuana (Murray, 1913) & & & W & & & & & & W & & & & & & & & & 2 \\
\hline \multicolumn{19}{|c|}{ Family Synchaetidae Hudson and Gosse, 1886} \\
\hline 19. Polyarthra vulgaris Carlin, 1943 & & $\mathrm{C} / \mathrm{W}$ & & & & & & & & & & & & & & & & 1 \\
\hline 20. Synchaeta oblonga Ehrenberg, 1831 & & & & & & $\mathrm{C}$ & & & & & & & & & & & & 1 \\
\hline \multicolumn{19}{|l|}{ Family Trichotriidae Harring, 1913} \\
\hline 21. Macrochaetus sp. & & & & & & & & & & W & & & & & & & & 1 \\
\hline S Subtotal C & 6 & 9 & 8 & 8 & 7 & 1 & 4 & 2 & 1 & 2 & 3 & 2 & 6 & 5 & 5 & 0 & 3 & \\
\hline S Subtotal W & 6 & 11 & 10 & 4 & 4 & 0 & 2 & 1 & 3 & 1 & 1 & 1 & 2 & 1 & 0 & 2 & 3 & \\
\hline$S$ Grand Total & 8 & 12 & 10 & 9 & 8 & 1 & 4 & 2 & 3 & 3 & 3 & 2 & 7 & 5 & 5 & 2 & 4 & \\
\hline
\end{tabular}




\subsection{Abundance and Biomass}

The rotifer abundance ranged from 0 to 538 ind $\mathrm{L}^{-1}\left(42 \pm 131\right.$ ind $\left.\mathrm{L}^{-1}\right)$ in the cold/dry season and from 0 to 227 ind $\mathrm{L}^{-1}\left(20 \pm 55\right.$ ind $\left.\mathrm{L}^{-1}\right)$ in the warm/rainy seasons. No significant difference (Student's $t$-tests, $n=34, t=1.155, p=0.265$ ) was found between seasons. The highest abundance was recorded in the shallow and eutrophic lakes Balantetic $\left(C=120, W=17\right.$ ind $\left.\mathrm{L}^{-1}\right)$ and Chajchaj $(C=538$, $\mathrm{W}=227$ ind $\left.\mathrm{L}^{-1}\right)$, followed by the deep eutrophic lakes San Lorenzo $\left(C=17, W=60\right.$ ind $\left.\mathrm{L}^{-1}\right)$, Bosque Azul $\left(C=20, W=26\right.$ ind $\left.L^{-1}\right)$, and La Encantada $\left(C=23, W=3\right.$ ind $\left.L^{-1}\right)$. No significant difference (Student's $t$-tests, $n=10, t=-2.239, p=0.056$ ) was found between the shallow and deep eutrophic lakes. All the oligotrophic lakes, regardless of their water depth, had a very low abundance of less than 2 ind $\mathrm{L}^{-1}$ (Table 3). No significant difference (Student's $t$-tests, $n=24, t=-1.245, p=0.235$ ) was found between the shallow and deep oligotrophic lakes. However, we did find a significant difference (Student's $t$-tests, $n=34, t=3.133, p=0.004$ ) between the eutrophic lakes (with higher abundance) and the oligotrophic lakes (with lower abundance) (Figure 2).
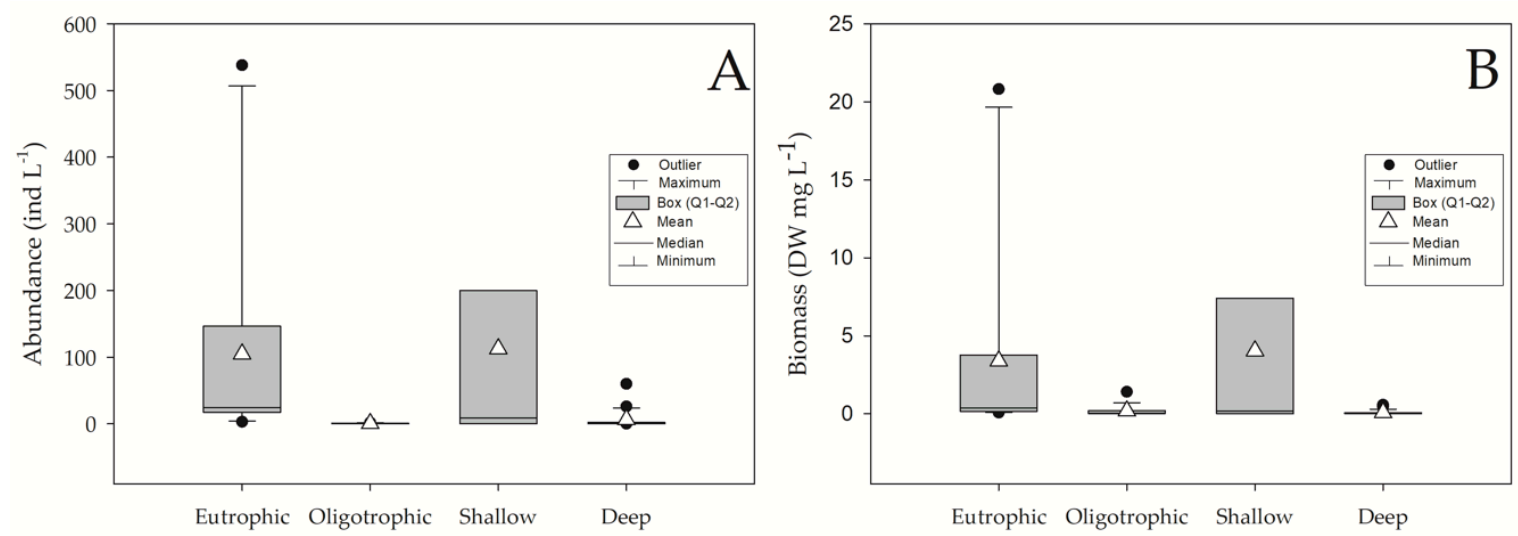

Figure 2. Pelagic rotifer abundance (A) and dry biomass (B) boxplots of the eutrophic $(n=5)$, oligotrophic $(n=12)$, shallow $(n=4)$ and deep $(n=13)$ lakes of the PNLM, Chiapas, Mexico.

The rotifer biomass ranged (minimum to maximum) from 0 to $20.82 \mu \mathrm{g} \mathrm{L}^{-1}\left(2.20 \pm 5.40 \mu \mathrm{g} \mathrm{L}^{-1}\right)$ for the cold/dry season and from 0 to $1.95 \mu \mathrm{g} \mathrm{L}^{-1}\left(0.2 \pm 0.5 \mu \mathrm{g} \mathrm{L}^{-1}\right)$ for the warm/rainy season. No significant difference (Student's $t$-tests, $n=34, t=2.78, p=0.797$ ) was found between the seasons. The biomass followed a pattern similar to that of abundance: The shallow eutrophic lakes had the highest values $\left(8.1 \pm 9.3,0.3\right.$ to $\left.2.10 \mu \mathrm{g} \mathrm{L}^{-1}\right)$ followed by the deep eutrophic lakes $(0.26 \pm 0.19,0.07$ to $0.57 \mu \mathrm{g} \mathrm{L}^{-1}$ ), while all the oligotrophic lakes had biomass values less than $0.04 \mu \mathrm{g} \mathrm{L}^{-1}$ (Table 3 ). Similar to abundance, no significant differences were found between the shallow and deep eutrophic (Student's $t$-tests, $n=10, t=-1.602, p=0.148$ ) or shallow and deep oligotrophic (Student's $t$-tests, $n=24, t=-1.522, p=0.142$ ) lakes. In contrast, a significant difference (Student's $t$-tests, $n=34$, $t=2.514, p=0.017$ ) was found between the eutrophic lakes (which had higher biomass values) and the oligotrophic lakes (which had lower biomass values) (Figure 2).

The highest densities ( $>100$ ind $\left.\mathrm{L}^{-1}\right)$ were observed for only three species $(14 \%$ of all identified rotifer taxa) - K. americana (Nmax 260 ind $\mathrm{L}^{-1}$ in Chajchaj), K. tropica (Nmax 140 ind $\mathrm{L}^{-1}$ in Chajchaj), and T. patina (Nmax 102 ind $\mathrm{L}^{-1}$ in Balantetic)—during the cold/dry season, and only one species ( $5 \%$ of the total identified rotifer taxa) - K. americana (Nmax 100 ind $\mathrm{L}^{-1}$ in Chajchaj)-during the warm/rainy season.

For the cold/dry season, the biomass of $86 \%$ of the species was less than $1 \mu \mathrm{g} \mathrm{L}^{-1}$, the highest biomasses $\left(>1 \mu \mathrm{g} \mathrm{L}^{-1}\right)$ were observed again only in three species, T. patina (Bmax $18.7 \mu \mathrm{g} \mathrm{L}-1$ in Balantetic), K. americana (Bmax $1.3 \mu \mathrm{g} \mathrm{L}{ }^{-1}$ in Chajchaj), and A. girodi (Bmax $1.16 \mu \mathrm{g} \mathrm{L}{ }^{-1}$ in Chajchaj). In the warm/rainy season, the biomass of $95 \%$ of the species was less than $0.2 \mu \mathrm{g} \mathrm{L}-1$, only K. americana contributed the most to the biomass with $0.5 \mu \mathrm{g} \mathrm{L}-1$ in Lake Chajchaj. 
Table 3. Species richness (S), abundance (N), and dry biomass (B) of the planktonic rotifer assemblages of the lakes of the PNLM, Chiapas, Mexico. (Abr- = lakes' names abbreviation as in Table 1.).

\begin{tabular}{|c|c|c|c|c|c|c|c|}
\hline & \multirow{2}{*}{ Lake } & \multicolumn{3}{|c|}{ Cold/Dry } & \multicolumn{3}{|c|}{ Warm/Rainy } \\
\hline & & $S$ & $N\left(\right.$ ind $\left.L^{-1}\right)$ & B $\left(\mu \mathrm{g} \mathrm{L}^{-1}\right)$ & $S$ & $N\left(\right.$ ind $\left.L^{-1}\right)$ & B $\left(\mu \mathrm{g} \mathrm{L}^{-1}\right)$ \\
\hline \multirow{5}{*}{ Eutrophic } & Balantetic & 6 & 120 & 20.82 & 6 & 17 & 0.31 \\
\hline & Chajchaj & 9 & 538 & 9.23 & 11 & 227 & 1.95 \\
\hline & San Lorenzo & 8 & 17 & 0.23 & 10 & 60 & 0.57 \\
\hline & Bosque Azul & 8 & 20 & 0.12 & 4 & 26 & 0.43 \\
\hline & La Encantada & 7 & 23 & 0.16 & 4 & 3 & 0.07 \\
\hline \multirow{12}{*}{ Oligotrophic } & Esmeralda & 1 & $<0.1$ & $<0.01$ & 0 & 0.0 & 0.00 \\
\hline & Ensueño & 4 & 0.2 & $<0.01$ & 2 & 1.9 & 0.02 \\
\hline & Agua Tinta & 2 & 0.2 & $<0.01$ & 1 & 0.3 & 0.01 \\
\hline & San Jose & 1 & 1.4 & 0.04 & 3 & 1.3 & 0.01 \\
\hline & Montebello & 2 & 0.1 & $<0.01$ & 1 & 0.6 & 0.01 \\
\hline & Cinco Lagos & 3 & 0.1 & $<0.01$ & 1 & 0.5 & 0.01 \\
\hline & Pojoj & 2 & 0.7 & 0.01 & 1 & 0.2 & $<0.01$ \\
\hline & Kitchail & 6 & 0.7 & 0.04 & 2 & 1.8 & 0.03 \\
\hline & Tziscao & 5 & 1.1 & 0.02 & 1 & 0.1 & $<0.01$ \\
\hline & Pataniu & 5 & 1.1 & 0.02 & 0 & 0.0 & 0.00 \\
\hline & Yalalush & 0 & 0.0 & 0.00 & 2 & 0.3 & $<0.01$ \\
\hline & Dos Lagos & 3 & 0.3 & $<0.01$ & 3 & 0.3 & 0.02 \\
\hline
\end{tabular}

\subsection{Multivariate Analysis}

The cluster analysis (Bray Curtis index) showed two main groups and one lake (cut at a dissimilarity distance of 0.97) (Figure 3). The first group was comprised of 11 lakes, all of them oligotrophic (10 deep and 1 shallow). All these lakes shared a lower rotifer abundance values compared with the other group. The second group incorporated the five eutrophic lakes (three deep and two shallow). The five lakes of the second group showed higher rotifer abundance. Lake Esmeralda, that was not placed in either of these two groups, is the lake-oligotrophic with the lowest rotifer abundance of all.

The SIMPER analysis showed Keratella americana explained the maximum dissimilarity between oligotrophic and eutrophic lakes $(\sim 52 \%)$, as well as between shallow and deep lakes $(\sim 38 \%)$; the other rotifer species contributed with $<20 \%$ of the total dissimilarity (Supplemental Materials Table S1).

For the two CCAs, a $p<0.05$ (Monte Carlo permutation test) was observed for the first two axes, as well as VIF values for both CCAs were less than 6 , so it was not necessary to eliminate any of the variables. Both canonical correspondence analyses (abundance-based and biomass-based) showed similar results (Figure 4). The lakes were separated into two groups on the first component according to their trophic status, and the abundance and biomass of Copepoda and Cladocera. With the highest densities and biomasses of Copepoda and Cladocera, the eutrophic lakes are located on the right side of the diagrams, while the oligotrophic lakes with lowest densities and biomasses placed on the left side.

In the second component, the water depth (shallow = warm polymictic, deep = warm monomictic), separated the lakes. The shallow and warm polymictic lakes were on the upper part of the diagrams, while the deep and warm monomictic lakes were on the lower part. The species were grouped together with the lakes in which they were present in higher densities and biomasses; the higher densities and biomass clustered towards the right side of the diagrams, while the lower densities and biomass clustered towards the left side (Figure 4). 


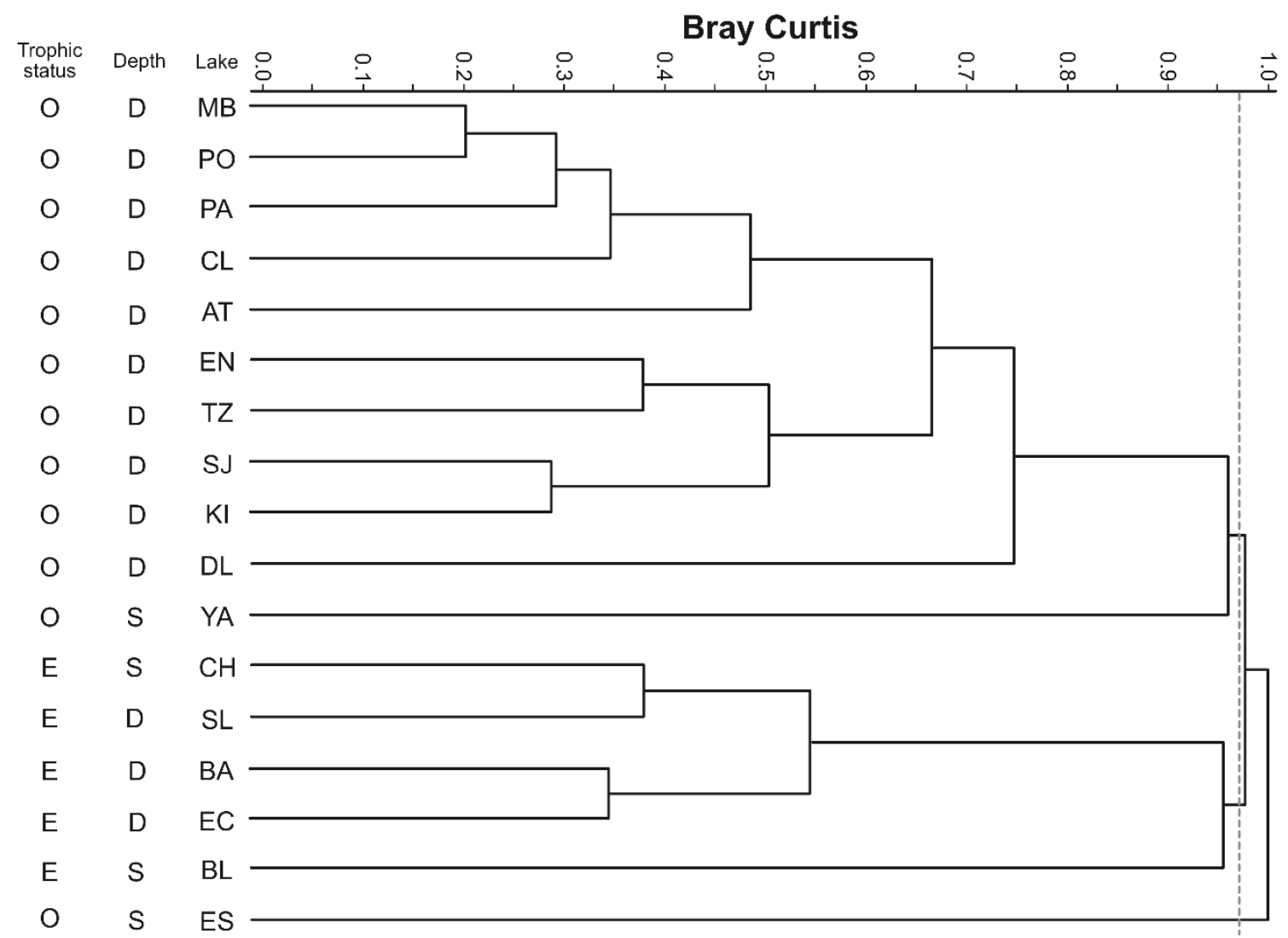

Figure 3. Dendrogram based on abundance values of the rotifer species (Bray Curtis dissimilarity index) lakes of the PNLM, Chiapas, Mexico. (Abbreviations of the lakes' names as in Table 1. S = Functionally shallow lakes; $\mathrm{D}=$ deep lakes; $\mathrm{O}=$ oligotrophic lakes; $\mathrm{E}=$ eutrophic lakes).
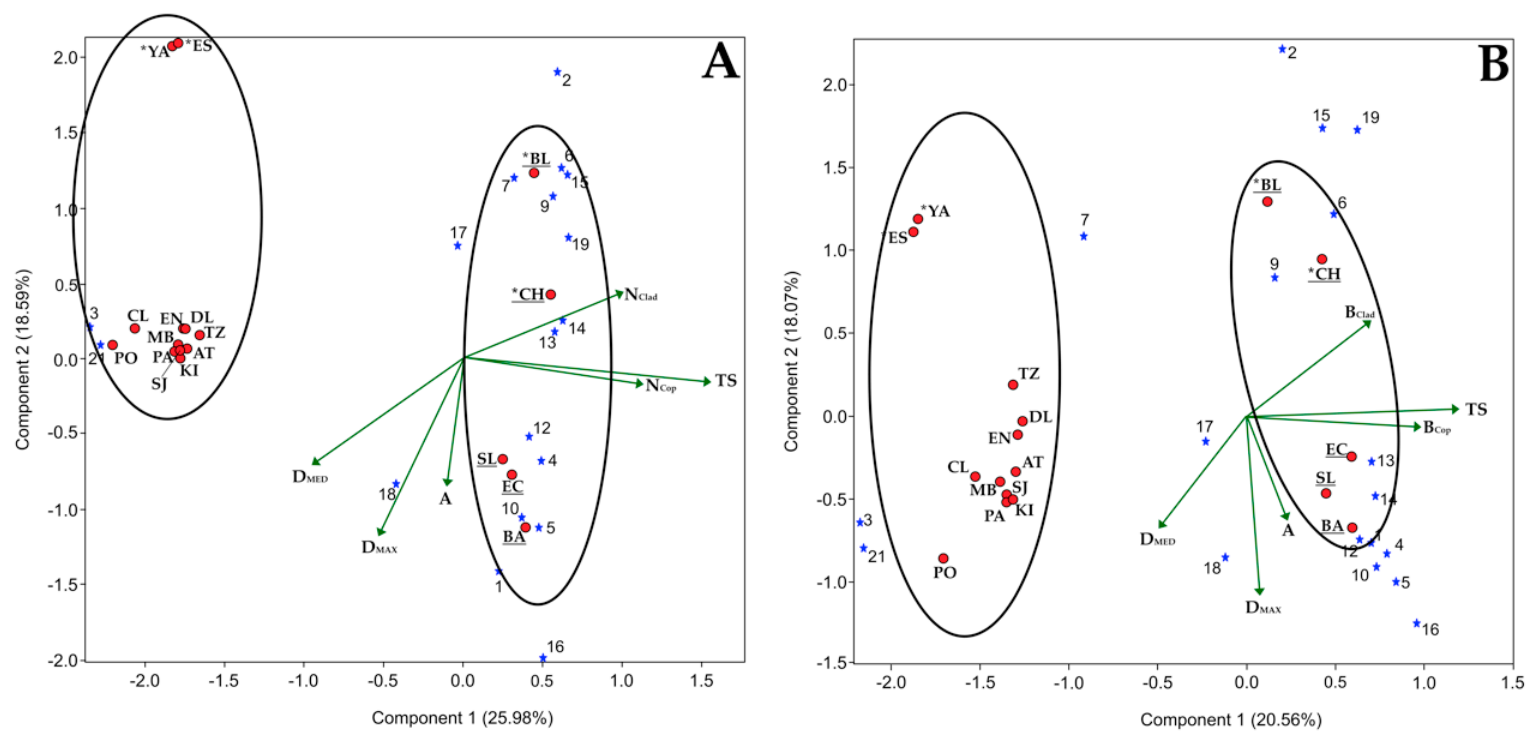

Figure 4. Canonical correspondence analysis (CCA) triplots of the pelagic rotifers of the PNLM, Chiapas, Mexico (A) based on rotifer abundance, and (B) based on rotifer biomass. Lakes are indicated by red circles (the abbreviations of the lakes' names as in Table 1). Rotifer species are indicated by blue asterisks (the numbers are the species' names as in Table 2). The arrows represent the environmental constraints $\left(\mathrm{A}=\right.$ surface area, $\mathrm{D}_{\mathrm{MAX}}=$ maximum depth, $\mathrm{D}_{\mathrm{MED}}=$ mean depth, $\mathrm{TS}=$ trophic status (chlorophyll "a" concentration), $\mathrm{N}_{\text {Cop }}=$ total abundance of Copepoda, $\mathrm{N}_{\text {Clad }}=$ total abundance of Cladocera, $\mathrm{B}_{\mathrm{Cop}}=$ total biomass of Copepoda, and $\mathrm{B}_{\mathrm{Clad}}=$ total biomass of Cladocera). 


\section{Discussion}

The ample climatic (convergence of temperate and tropical zones) and orographic heterogeneity in Mexico results in an enormous diversity of aquatic ecosystems (Nearctic and Neotropical biogeographic regions conjunction) that has played a very important role in the development of diverse inland water communities [3]. Rotifer inventories of Mexican inland waters report species richness values of 10-125 in rivers [9,11], 7-60 in reservoirs [7-9], 10-65 in oligotrophic [10,45], and 35-80 in eutrophic lakes [9,12]; however, our 21 pelagic rotifer species richness for the PNLM lakes is on the lower limit of those ranges. It is noteworthy that the low biodiversity recorded in the pelagic rotifer assemblage from the lakes of the PNLM matches the low biodiversity reports for other biological assemblages (e.g., benthic macroinvertebrates [46]) of these same lakes.

At a regional scale, the study of Arroyo-Castro et al. [15] in 17 sinkholes from the Cozumel Island, Quintana Roo, showed 36 rotifer species richness, ranging from 0 to 19 species per water body. Although the number of the studied water bodies is equal to our study, the regional (36) species richness of Arroyo-Castro et al. [15] is higher than ours in the PNLM (21). It must be noted that 17 $(47 \%)$ of the species found in the Cozumel Island were registered only in 1-3 water bodies, which is a similar case to the lakes of the PNLM with 11 species (52\%) in 1-3 lakes.

In the Chihuahan desert, the northern Mexican arid zone, Walsh et al. [13] reported 59 rotifer species from 47 saline water bodies, ranging from 1 to 15 species per water body. Once again, $50 \%$ of the reported species were found in just a few water bodies. Rios-Arana et al. [14] found a similar singularity ( $50 \%$ of the species present in a single water body) in seven desert springs of the Chihuahan desert, with a species richness of 57 ranging from 1 to 28 species per water body.

All the 21 rotifer species found in the PNLM lakes during the present study have already been reported from water bodies in easter/southeastern Mexico [47,48]; most of the species herein recorded are considered cosmopolitan. Keratella americana is commonly found in the Americas, Brachionus havanaensis and Hexarthra intermedia are neotropical, while Lecane papuana is tropicopolitan [48]. Other species found in the PMLM lakes (e.g., Lecane bulla, Brachionus calyciflorus, and Platyias quadricornis) show large genetic variability [47], indicating that they constitute cryptic species complexes.

Environmentally, based on the studied parameters the lakes of the PNLM differed just in their trophic status (chlorophyll-a concentrations) but in no other environmental characteristics (e.g., temperature, dissolved oxygen, $\mathrm{pH}$ ) (Alcocer et al. [31]). It is well known that eutrophic lakes have higher concentrations of nutrients, chlorophyll-a, seston, and particulate organic carbon compared to the oligotrophic lakes. Accordingly, although the rotifer abundance of the lakes of the PNLM varied widely between species and lakes (from 0 to 538 ind $\mathrm{L}^{-1}$ ), the largest differences were between the eutrophic lakes (average of $105 \pm 167$ ind $\mathrm{L}^{-1}$ ) and the oligotrophic lakes $\left(0.6 \pm 0.6\right.$ ind $\left.\mathrm{L}^{-1}\right)$. It should be noted that in the eutrophic lakes, only three species contributed $80 \%$ of the total abundance, which is also recorded in other studies from other eutrophic Mexican lakes (e.g., References $[12,49,50]$ ) with abundance values between 500 and 5000 ind $\mathrm{L}^{-1}$, with three to six species making up more than $70 \%$ of the total abundance.

Cervantes-Martínez and Gutiérrez-Aguirre [51] report an average abundance of most rotifers' species ranging from 0 to 20 ind $\mathrm{L}^{-1}$, where $K$. americana is the most abundant species; these figures and the dominant species are similar to our study. Although biomass of rotifers is not often reported, in tropical lakes, biomass varies from 5 to $10 \%$ of the total zooplankton biomass $[35,52,53]$. The rotifer biomass of the PNLM lakes contributed a similar percentage (5\%) to the total zooplankton [54]

Several authors $[19,22,55]$ mention that the species richness and abundance of zooplankton have a positive relationship with the primary productivity of lakes because, when there is more food available in an aquatic system, there is the potential to support more species and in higher densities. Accordingly, it would be expected to have higher values of rotifer species richness and abundance in the eutrophic lakes, while lower in the oligotrophic [55], which was the case in PNLM lakes where eutrophication influenced the rotifer assemblages by augmenting species richness, abundance, and biomass. 
Our findings showed a simple rotifer assemblage of the PNLM lakes, for the lower limit of reported species richness ranges in the Mexican area. There is not a simple explanation that could be provided on this; however, some arguments could be considered. First, it must be noted that our regional study involved water bodies of the same type (all karstic lakes), while other regional studies report the biodiversity from various water body types present in the region (e.g., temporal, perennial, lakes, ponds, spring, rivers, streams), which most likely results in higher biodiversity. Second, even though the regional species accumulation curve suggests that the regional species richness value (21) is close to the actual species richness present in the lakes of the PNLM, two methodological concerns must be mentioned. a) Most rotifer studies use nets with smaller mesh size (35- $\mu \mathrm{m}$ or $25-\mu \mathrm{m}$, References [56-58]) than our (54- $\mu \mathrm{m})$. b) Rotifer biodiversity studies usually report species from both the littoral and the pelagic zones (e.g., References [7-9,12]), while ours included just the pelagic zone. Lower diversity in the pelagic zone is usually associated with its homogeneity compared with the littoral zone [59].

Alcocer et al. [31] found the PNLM lakes are environmentally similar (e.g., morphometry, water chemistry) to other karstic lakes worldwide. So, if environmental variables apparently are not playing a major role in explaining the comparative simplicity of the rotifer assemblage of the Montebello lakes, it could be assumed that biological variables are important in defining the rotifer biodiversity in the lakes of the PNLM. Although trophic relations are the way the food web functions in oligotrophic and eutrophic lakes worldwide, the specific combination of factors could result in different final scenarios. We herein discuss two factors (food availability—quantity and quality—and competition/predation) are interplaying differently in oligo and eutrophic lakes, so rotifers could be controlled by starvation plus predation in eutrophic lakes, and by starvation plus competition in oligotrophic lakes.

Food availability (phytoplankton type and quantity) is probably influencing rotifers differently in oligo and eutrophic lakes of the PNLM. In the oligotrophic lakes, phytoplankton is represented by small centric diatoms (Cyclotella) [31], a "high-quality" food but in rather limited amount $\left(<2 \mu \mathrm{g} \mathrm{L}^{-1}\right.$, Vera-Franco et al. [35]). On the other hand, in eutrophic lakes of the PNLM, phytoplankton is dominated ( $95 \%$ ) by large filamentous -40 to $>100 \mu \mathrm{m}$-cyanobacteria (e.g., Limnothrix, Planktothrix and Cylindrospermopsis [54]), a "low quality" food (e.g., hard to manage, low nutritional value with insufficient essential components, production of cyanotoxins [60-63], but rather abundant $\left(>14 \mu \mathrm{g} \mathrm{L}^{-1}\right.$, Vera-Franco et al. [35]). In both cases, rotifers could be limited by competition for better-quality food $[64,65]$, which often leads to lower rotifer fitness as observed in other studies [66].

In addition to the low "high quality" food availability, the zooplankton community of the eutrophic lakes of the PNLM includes numerous species of cyclopoid copepods [67], which are natural predators of rotifers. Microcyclops ceibaensis and Thermocyclops inversus are characteristic examples of cyclopoid copepods inhabiting the eutrophic lakes of the PNLM [67]. Cyclopoid copepods composed $40 \pm 15 \%$ of the total zooplankton biomass of the eutrophic lakes of the PNLM [54]. Therefore, copepods predation $[68,69]$ could also be limiting rotifers in the eutrophic lakes of the PNLM.

On the other hand, in the oligotrophic lakes of the PNLM, the competitive interference with more efficient macrofiltering zooplankton (e.g., Reference [70]) could be another factor playing against the rotifers. The macrofiltering zooplankton of the oligotrophic lakes of the PNLM is represented by calanoid copepods (Mastigodiaptomus maya, M. nesus, and Aglodiaptomus clavipes) and cladocerans (Daphnia gessneri and D. galeata) [39]. Calanoid copepods and cladocerans composed $71 \pm 13 \%$ and $15 \pm 10 \%$, respectively, of the total zooplankton biomass of the oligotrophic lakes of the PNLM (Fernández, unpublished data). Therefore, competitive interference [57] by filter-feeding copepods and cladocerans could be probably limiting rotifers in the oligotrophic lakes of the PNLM. Of course, we acknowledge mentioned that there might other factors not examined here involved in explaining the comparative simplicity of the rotifer assemblage of the Montebello lakes.

In summary: (a) The regional and individual biodiversity (per lake) of planktonic rotifers of the PNLM is low (regional diversity $=21$, per lake diversity $=1$ to 12 ) compared to that reported for other Mexican epicontinental aquatic bodies and other tropical and temperate lakes. (b) The trophic status 
was the variable that had the greatest influence on classifying lakes into two groups: Eutrophic lakes (which had higher species richness, abundance, and biomass of planktonic rotifers), and oligotrophic lakes (which had lower species richness, abundance, and biomass of planktonic rotifers). (c) The general low "high-quality" food-phytoplankton—availability coupled with predation pressure (cyclopoid copepods) and cyanotoxins presence in eutrophic lakes, and competitive interference (calanoid copepods) in oligotrophic lakes, most likely explain the simplicity of the rotifer community in the lakes of the PNLM. (d) The lakes of the PNLM showed high distinctiveness (singularity) in species composition, with most species inhabiting just one to three aquatic bodies of the lake districts.

Supplementary Materials: The following are available online at http://www.mdpi.com/1424-2818/12/12/454/s1, Figure S1: Accumulation curve of species of pelagic rotifers in 17 lakes of the PNLM, Chiapas, Mexico, Table S1: SIMPER analysis showing the contribution of each specie according to average Bray Curtis dissimilarity between group of depth and trophic status of lakes of the PNLM, Chiapas, Mexico. (Av. Abund. = average abundance, Av. Diss. = average dissimilarity, Contrib. $\%=$ percentage contribution, Cum. $\%=$ cumulative contribution percentage, Av. Dissimilarity = average dissimilarity).

Author Contributions: R.F.: conceptualization, methodology, validation, formal analysis, investigation, data curation, writing - original draft preparation, visualization. J.A.: conceptualization, validation, investigation, resources, writing - review and editing, visualization, supervision, project administration, funding acquisition. L.A.O.: methodology, software, validation, formal analysis, investigation, data curation, writing-original draft preparation, visualization, project administration. All authors have read and agreed to the published version of the manuscript.

Funding: This research was funded by the Fondo Sectorial de Investigación y Desarrollo Sobre el Agua CONAGUA-CONACYT through project 167603 and by DGAPA/UNAM through Projects PAPIIT-IN219215 and PAPIIT-IV200319.

Acknowledgments: We thank René Morales Hernández and collaborators for support during the fieldwork. We also thank the Parque Nacional Lagunas de Montebello, Comisión Nacional de Áreas Naturales Protegidas (CONANP) (Jesús A. León and Roberto Castellanos), the local community, and the Comisariados Ejidales from Antelá, Cárdenas, Miguel Hidalgo, Ojo de Agua, and Tziscao for facilitating access to the lakes. We also thank the Comité de Administración de Tziscao (Sergio Marcos and Miguel A. Tomas), Presidente del Comité de Turismo de Tziscao (Armando Hernández), Comisario Ejidal de Tziscao (Enrique M. Hernández), and personnel of the Villas Tziscao Hotel (Rosemberg F. Jorge, Juan G. Espinoza and Gemuel P. Hernández) for offering their support and facilities for this study. The statistical advice of Benjamín Quiroz is greatly appreciated. The authors express great appreciation to the many referees whose expert comments resulted in a substantial improvement of the manuscript.

Conflicts of Interest: The authors declare no conflict of interest.

\section{References}

1. Hanly, P.J.; Mittelbach, G.G.; Schemske, D.W. Speciation and the latitudinal diversity gradient: Insights from the global distribution of endemic fish. Am. Nat. 2017, 189, 604-615. [CrossRef] [PubMed]

2. Koleff, P.; Urquiza-Haas, T.; Ruiz-González, S.P.; Hernández-Robles, D.R.; Mastretta-Yanes, A.; Quintero, E.; Sarukhán, J. Biodiversity in Mexico: State of Knowledge. In Global Biodiversity: Volume 4: Selected Countries in the Americas and Australia; Pullaiah, T., Ed.; CRC Press: Boca Raton, FL, USA, 2018.

3. Alcocer, J.; Aguilar-Sierra, V. Biodiversity in inland waters. In Mexican Aquatic Environments. A General View from Hydrobiology to Fisheries; Ibañez, A.L., Ed.; Springer: Berlin, Germany, 2019.

4. Alcocer, J.; Azpra, E.; Falcón, L.; Gallegos, A.; García, F.; García-Oliva, F.; Jaramillo, V.; Lecuanda, R.; Magaña, V.; Martínez-Yrizar, A.; et al. Diversidad de procesos funcionales en los ecosistemas. In Capital natural de México Vol. 1 Conocimiento actual de la biodiversidad; Escobar, E., Maas, M., Eds.; CONABIO: Ciudad de México, Mexico, 2008.

5. Martínez-Meyer, E.; Sosa-Escalante, J.E.; Álvarez, F. El estudio de la biodiversidad en México: ¿una ruta con dirección? Rev. Mex. Biodivers. 2014, 85, 1-9. [CrossRef]

6. Sarma, S.S.S.; Nandini, S. Rotíferos Mexicanos (Rotifera); Manual de Enseñanza; UNAM: Toluca, Mexico, 2017.

7. Nandini, S.; Merino-Ibarra, M.; Sarma, S.S.S. Seasonal changes in the zooplankton abundances of the reservoir Valle de Bravo (State of Mexico, Mexico). Lake Reserv. Manag. 2008, 24, 321-330. [CrossRef]

8. Vázquez-Sánchez, A.; Reyes-Vanegas, G.; Nandini, S.; Sarma, S.S.S. Diversity and abundance of rotifers during an annual cycle in the reservoir Valerio Trujano (Tepecoacuilco, Guerrero, Mexico). Inland Waters 2014, 4, 293-302. [CrossRef] 
9. Rico-Martínez, R.; Silva-Briano, M. Contribution to the knowledge of the rotifera of Mexico. In Rotifer Symposium VI. Developments in Hydrobiology; Gilbert, J.J., Lubzens, E., Miracle, M.R., Eds.; Springer: Dordrecht, The Netherlands, 1993; pp. 467-474.

10. Sarma, S.S.S.; Elías-Gutiérrez, M. Rotifers (Rotifera) from four natural water bodies of Central Mexico. Limnologica 1999, 29, 475-483. [CrossRef]

11. Nandini, S.; Sarma, S.S.S.; Gulati, R.D. A seasonal study reveals the occurrence of exotic rotifers, the River Antigua, Veracruz, close to the Gulf of Mexico. River Res. Appl. 2017, 33, 970-982. [CrossRef]

12. Nandini, S.; Ramírez-García, P.; Sarma, S.S.S. Seasonal variations in the species diversity of planktonic rotifers in Lake Xochimilco, Mexico. J. Freshw. Ecol. 2005, 20, 287-294. [CrossRef]

13. Walsh, E.J.; Schröder, T.; Wallace, R.L.; Ríos-Arana, J.V.; Rico-Martinez, R. Rotifers from selected inland saline waters in the Chihuahuan Desert of Mexico. Saline Syst. 2008, 4. [CrossRef]

14. Ríos-Arana, J.V.; Agüero-Reyes, L.C.; Wallace, R.L.; Walsh, E.J. Limnological characteristics and rotifer community composition of Northern México Chihuahuan Desert springs. J. Arid Environ. 2019, 160, 32-41. [CrossRef]

15. Arroyo-Castro, J.L.; Alvarado-Flores, J.; Uh-Moo, J.C.; Koh-Pasos, C.G. Monogonont rotifers species of the Island Cozumel, Quintana Roo, Mexico. Biodivers. Data J. 2019, 7, e34719. [CrossRef]

16. Quintana, X.D.; Arim, M.; Badosa, A.; Blanco, J.M.; Boix, D.; Brucet, S.; Compte, J.; Egozcue, J.J.; de Eyto, E.; Gaedke, U.; et al. Predation and competition effects on the size diversity of aquatic communities. Aquat. Sci. 2014, 77, 45-57. [CrossRef]

17. Aránguiz-Acuña, A.; Pérez-Portilla, P.; De la Fuente, A.; Fontaneto, D. Life-history strategies in zooplankton promote coexistence of competitors in extreme environments with high metal content. Sci. Rep. 2018, 8, 1-10. [CrossRef] [PubMed]

18. Choi, J.-Y.; Kim, S.-K. Responses of Rotifer Community to Microhabitat Changes Caused by Summer-Concentrated Rainfall in a Shallow Reservoir, South Korea. Diversity 2020, 12, 113. [CrossRef]

19. Karpowicz, M.; Ejsmont-Karabin, J.; Kozłowska, J.; Feniova, I.; Dzialowski, A.R. Zooplankton Community Responses to Oxygen Stress. Water 2020, 12, 706. [CrossRef]

20. Shurin, J.B.; Winder, M.; Adrian, R.; Keller, W.; Matthews, B.; Paterson, A.M.; Paterson, M.J.; Pinel-Alloul, B.; Rusak, J.A.; Yan, N.D. Environmental stability and lake zooplankton diversity-contrasting effects of chemical and thermal variability. Ecol. Lett. 2010, 13, 453-463. [CrossRef]

21. Kaya, M.; Fontaneto, D.; Segers, H.; Altindağ, A. Temperature and salinity as interacting drivers of species richness of planktonic rotifers in Turkish continental waters. J. Limnol. 2010, 69, 297-304. [CrossRef]

22. Oksanen, L.; Fretwell, S.D.; Arruda, J.; Niemela, P. Exploitation ecosystems in gradients of primary productivity. Am. Nat. 1981, 131, 424-444. [CrossRef]

23. Hoffmann, M.D.; Dodson, S.I. Land use, primary productivity, and lake area as descriptors of zooplankton diversity. Ecology 2005, 86, 255-261. [CrossRef]

24. Schuler, M.S.; Chase, J.M.; Knight, T.M. Habitat size modulates the influence of heterogeneity on species richness patterns in a model zooplankton community. Ecology 2017, 98, 1651-1659. [CrossRef]

25. Scherer, L.; Pfister, S. Global biodiversity loss by freshwater consumption and eutrophication from Swiss food consumption. Environ. Sci. Technol. 2016, 50, 7019-7028. [CrossRef]

26. Monchamp, M.E.; Spaak, P.; Domaizon, I.; Dubois, N.; Bouffard, D.; Pomati, F. Homogenization of lake cyanobacterial communities over a century of climate change and eutrophication. Nat. Ecol. Evol. 2018, 2, 317-324. [CrossRef] [PubMed]

27. Barnett, A.; Beisner, B.E. Zooplankton biodiversity and lake trophic state: Explanations invoking resource abundance and distribution. Ecology 2007, 88, 1675-1686. [CrossRef] [PubMed]

28. Cook, S.C.; Housley, L.; Back, J.A.; King, R.S. Freshwater eutrophication drives sharp reductions in temporal beta diversity. Ecology 2018, 99, 47-56. [CrossRef] [PubMed]

29. Liu, P.; Xu, S.; Lin, J.; Li, H.; Lin, Q.; Han, B.P. Urbanization increases biotic homogenization of zooplankton communities in tropical reservoirs. Ecol. Indic. 2020, 110, 105899. [CrossRef]

30. Alcocer, J.; Oseguera, L.A.; Sanchez, G.; Gonzalez, C.G.; Martinez, J.R.; Gonzalez, R. Bathymetric and morphometric surveys of the Montebello Lakes, Chiapas. J. Limnol. 2016, 75, 56-65. [CrossRef]

31. Alcocer, J.; Merino-Ibarra, M.; Oseguera, L.A.; Escolero, O. Anthropogenic impacts on tropical karst lakes: "Lagunas de Montebello" Chiapas. Ecohydrology 2018, 11, e2029. [CrossRef] 
32. CONANP. Estudio para el Monitoreo de Calidad del agua de las Lagunas en el Parque Nacional Lagunas de Montebello, Chiapas; Comisión Nacional de Áreas Naturales Protegidas: Ciudad de México, Mexico, 2009; pp. 15-35.

33. García, E. Modificaciones al Sistema de Clasificación Climática de Köppen; Instituto de Geografía, UNAM: Ciudad de México, Mexico, 2004; p. 97.

34. Durán Calderón, I.; Escolero-Fuentes, O.A.; Muñoz Salinas, E.; Castillo-Rodríguez, M.; Silva-Romo, G. Cartografía geomorfológica a escala 1:50,000 del Parque Nacional Lagunas de Montebello, Chiapas (México). Boletín de la Sociedad Geológica Mexicana 2014, 66, 263-277. [CrossRef]

35. Vera-Franco, M.; Hernández-Victoria, P.; Alcocer, J.; Ardiles-Gloria, V.; Oseguera, L.A. Concentración y distribución vertical de la clorofila-a fitoplanctónica en los lagos de Montebello, Chiapas. In Tendencias de Investigación en Limnología Tropical: Perspectivas Universitarias en Latinoamérica; Instituto de Ciencias del Mar y Limnología, UNAM; Alcocer, J., Merino-Ibarra, M., Escobar-Briones, E., Eds.; y Consejo Nacional de Ciencia y Tecnología: Ciudad de México, Mexico, 2015; pp. 107-114. Available online: http://cc-catalogo.org/site/pdf/ epifania.pdf (accessed on 1 October 2020).

36. Alcocer, J.; Prado, B.; Mora, L.; Oseguera, L.A.; Caballero, M. Sedimentary characteristics of tropical, karstic lakes and their relationship with topography, lake morphometry and anthropogenic activities. J. Paleolimnol. 2020, submitted.

37. Koste, W. Rotatoria. Die Rädertiere Mitteleuropas 1978, 2, 234-673.

38. Jersabek, C.D.; Leitner, M.F. Rotifer World Catalog. 2013. Available online: http://rotifera.hausdernatur.at/ (accessed on 1 October 2020).

39. Bonecker, C.C.; Nagae, M.Y.; Bletller, M.C.M.; Velho, L.F.M.; Lansac-To^ha, F.A. Zooplankton biomass in tropical reservoirs in southern Brazil. Hydrobiologia 2007, 579, 115-123. [CrossRef]

40. Ruttner-Kolisko, A. Suggestions for biomass calculation of plankton rotifers. Archiv für Hydrobiologie 1977, 8, 71-76.

41. Bottrell, H.H.; Duncan, A.; Gliwicz, Z.M.V.; Grygierek, E.; Herzig, A.; Hillbricht-Ilkowska, A.; Kurasawa, H.; Larsson, P.; Weglenska, T. A review of some problems in zooplankton production studies. Norweg. J. Zool. 1976, 24, 419-456.

42. Pace, M.L.; Orcutt, J.D., Jr. The relative importance of protozoans, rotifers and crustaceans in a freshwater zooplankton community. Limnol. Oceanogr. 1981, 26, 822-830. [CrossRef]

43. Ugland, K.I.; Gray, J.S.; Ellingsen, K.E. The species-accumulation curve and estimation of species richness. J. Anim. Ecol. 2003, 72, 888-897. [CrossRef]

44. R Core Team. R: A Language and Environment for Statistical Computing; R Foundation for Statistical Computing; R Core Team: Vienna, Austria, 2020. Available online: http://www.R-project.org/ (accessed on 1 October 2020).

45. Sarma, S.S.S.; Elias-Gutiérrez, M.; Serrania-Soto, C. Rotifers from high altitude crater-lales at Nevado de Toluca Volcano, México. Hidrobiologica 1997, 6, 33-38.

46. Cortés-Guzmán, D.; Alcocer, J.; Oseguera, L.A. Benthic macroinvertebrates community diversity of Montebello Lakes, Chiapas. Rev. Mex. Biodivers 2019, 90, e902769. [CrossRef]

47. García-Morales, A.E.; Elías-Gutiérrez, M. DNA barcoding of freshwater Rotifera in Mexico: Evidence of cryptic speciation in common rotifers. Mol. Ecol. Resour. 2013, 13, 1097-1107. [CrossRef]

48. García-Morales, A.E.; Elías-Gutiérrez, M. Rotifera from southeastern México, new records and comments on zoogeography. An. Inst. Biol. 2004, 75, 99-120.

49. Sarma, S.S.S.; Osnaya-Espinosa, L.R.; Aguilar-Acosta, C.R.; Nandini, S. Seasonal variations in zooplankton abundances in the Iturbide reservoir (Isidro Fabela, State of Mexico, Mexico). J. Environ. Biol. 2011, 32, 473-480.

50. Muñoz-Colmenares, M.E.; Sarma, S.S.S.; Nandini, S. Seasonal variations of rotifers from the high altitude Llano reservoir (State of Mexico, Mexico). J. Environ. Biol. 2017, 38, 1171-1181. [CrossRef]

51. Cervantes-Martínez, A.; Gutierrez-Aguirre, M.A. Physicochemistry and zooplankton of two karstic sinkholes in the Yucatan Peninsula, Mexico. J. Limnol. 2015, 74, 382-393.

52. Matsumara-Tundisi, T.; Rietzler, A.C.; Tundise, J.G. Biomass (dry weight and carbon content) of plankton Crustacea from Broa reservoir (São Carlos, SP, Brazil) and its fluctuation across one year. Hydrobiologia 1989, 149, 229-236. [CrossRef]

53. Sendacz, S.; Caleffi, S.; Santos-Soares, J. Zooplankton biomass of reservoirs in different trophic conations in the State of São Paulo, Brazil. Braz. J. Biol. 2006, 66, 337-350. [CrossRef] [PubMed] 
54. Fernández, R.; Alcocer, J.; Oseguera, L.A. Microcystins presence threatens the ecosystem health of a tropical National Park: Lagunas de Montebello, Chiapas. Braz. J. Bot. 2020. under review.

55. Dodson, S.I.; Arnott, S.E.; Cottingham, K.L. The relationship in lake communities between primary productivity and species richness. Ecology 2000, 81, 2662-2679. [CrossRef]

56. Chick, J.H.; Levchuk, A.P.; Medley, K.A.; Havel, J.H. Underestiamtion of rotifer abundance a much greater problem than previously appreciated. Limnol. Oceanogr. Methods 2010, 8, 79-87. [CrossRef]

57. Thomas, S.M.; Chick, J.H.; Czesny, S.J. Underestimation of microzooplankton is a macro problem: One size fits all zooplankton sampling needs alterations. J. Great Lakes Res. 2017, 43, 91-101. [CrossRef]

58. Brown, P.D.; Schröder, T.; Ríos-Arana, J.V.; Rico-Martinez, R.; Silva-Briano, M.; Wallace, R.L.; Walsh, E.J. Patterns of Rotifer Diversity in the Chihuahuan Desert. Diversity 2020, 12, 393. [CrossRef]

59. Da Silva Brito, M.T.; Heino, J.; Pozzobom, U.M.; Landeiro, V.L. Ecological uniqueness and species richness of zooplankton in subtropical floodplain lakes. Aquat. Sci. 2020, 82, 1-13.

60. Wilson, A.E.; Sarnelle, O.; Tilmanns, A.R. Effects of cyanobacterial toxicity and morphology on the population growth of freshwater zooplankton: Meta-analyses of laboratory experiments. Limnol. Oceanogr. 2006, 51, 1915-1929. [CrossRef]

61. Jia, J.; Shi, W.; Chen, Q.; Lauridsen, T.L. Spacial and temporal variations reveal the response of zooplankton to cyanobacteria. Harmful Algae 2017, 64, 63-73. [CrossRef] [PubMed]

62. Zamora-Barrios, C.A.; Nandini, S.; Sarma, S.S.S. Bioaccumulation of microcystins in seston, zooplankton and fish: A case study in Lake Zumpango, Mexico. Environ. Pollut. 2019, 249, 267-276. [CrossRef] [PubMed]

63. Elert, E.V.; Martin-Creuzburg, D.; Le Coz, J.R. Absence of sterols constrains carbon transfer between cyanobacteria and a freshwater herbivore (Daphnia galeata). Proc. R. Soc. Lond. Ser. B 2003, 270, 1209-1214. [CrossRef] [PubMed]

64. Krztoń, W.; Kosiba, J.; Pociecha, A.; Wilk-Woźniak, E. The effect of cyanobacterial blooms on bio-and functional diversity of zooplankton communities. Biodivers. Conserv. 2019, 28, 1815-1835. [CrossRef]

65. Ger, K.A.; Urrutia-Cordero, P.; Frost, P.C.; Hansson, L.A.; Sarnelle, O.; Wilson, A.E.; Lürling, M. The interaction between cyanobacteria and zooplankton in a more eutrophic world. Harmful Algae 2016, 54, 128-144. [CrossRef]

66. Ortega-Mayagoitia, E.; Ciros-Perez, J.; Sánchez-Martínez, M.A. A story of famine in pelagic realm: Temporal and special patterns of food limitation in rotifers from an oligotrophic tropical lake. J. Plankton Res. 2011, 33, 1574-1585. [CrossRef]

67. Fernández, R.; Alcocer, J.; Oseguera, L.A. Zooplankton biodiversity in tropical karst lakes of southeast Mexico, Chiapas. Rev. Mex. Biodivers. 2020, 91, e913184. [CrossRef]

68. Sarma, S.S.S.; Miracle, M.R.; Nandini, S.; Vicente, E. Predation by Acanthocyclops americanus (Copepoda: Cyclopoida) in the hypertrophic shallow waterbody, Lake Albufera (Spain): Field and laboratory observations. Hydrobiologia 2019, 829, 5-17. [CrossRef]

69. Valencia-Vargas, M.A.; Nandini, S.; Sarma, S.S.S. Demographic characteristics of two freshwater cyclopoid copepods in Mexico, fed a plankton diet: The native Mesocyclops longisetus Thiébaud and the invasive Mesocyclops pehpeinsis Hu. Inland Waters 2020, 10, 128-136. [CrossRef]

70. Balkić, A.G. The importance of environmental differences in the structuring of rotifer functional diversity. J. Limnol. 2019, 78. [CrossRef]

Publisher's Note: MDPI stays neutral with regard to jurisdictional claims in published maps and institutional affiliations.

(C) 2020 by the authors. Licensee MDPI, Basel, Switzerland. This article is an open access article distributed under the terms and conditions of the Creative Commons Attribution (CC BY) license (http://creativecommons.org/licenses/by/4.0/). 